\title{
Militant constitutionalism: a promising concept to make constitutional backsliding less likely?
}

\author{
Jerg Gutmann ${ }^{1,2} \cdot$ Stefan Voigt ${ }^{1,2}$ (D)
}

Received: 31 May 2019 / Accepted: 9 January 2021

(c) The Author(s) 2021

\begin{abstract}
Constitutional democracy is in decline and many would-be autocrats try to transgress constitutional constraints. Here, we introduce the concept of militant constitutionalism, which suggests a number of constitutional rules that could make constitutions more resilient to attempts to undermine them. A first empirical evaluation, however, can link only few constitutional paths to enhanced constitutional resilience.
\end{abstract}

Keywords Constitutional compliance $\cdot$ De jure-de facto gap $\cdot$ Democratic backsliding · Militant constitutionalism · Militant democracy

JEL classification $\mathrm{D} 73 \cdot \mathrm{H} 11 \cdot \mathrm{K} 16 \cdot \mathrm{K} 38 \cdot \mathrm{K} 42 \cdot \mathrm{P} 51$

\section{Introduction}

"History will teach us ... that of those men who have overturned the liberties of republics, the greatest number have begun their career by paying an obsequious court to the people, commencing demagogues and ending tyrants."

Alexander Hamilton, Federalist No. 1

This paper emerged out of the joint research project "The Economics of Compliance with Constitutions" supported by the DFG (381589259) and the NCN within the Beethoven 2 initiative. The authors thank the participants of the conference "The Freiburg School and the Virginia School: The Research Programs of Ordnungsökonomik and Constitutional Political Economy" and the EMLE Midterm Meeting Conference in Law and Economics, as well as Peter Niesen, Evangelia Nissioti, and in particular Hartmut Kliemt and Michael Munger for helpful comments.

Stefan Voigt

stefan.voigt@uni-hamburg.de

Jerg Gutmann

jerg.gutmann@uni-hamburg.de

1 Institute of Law and Economics, University of Hamburg, Johnsallee 35, 20148 Hamburg, Germany

2 CESifo, Munich, Germany 
Many observers have noted that constitutional democracies have come under stress. Examples of an executive's declining respect for the constitution include Hungary, the Philippines, Poland, Turkey and Venezuela. Frequently relied on indices of democracy as well as of political and civil rights confirm that these observations are part of a broader trend. In 2019, Freedom House counted the 14th consecutive year in which countries suffering from democratic setbacks outnumbered those registering gains. The Economist Intelligence Unit's Democracy Index registered the worst global democracy score in 2018 since its inception back in 2006.

After World War II, Germany has been following the slogan of "never again". It pledged to prevent the abolition of democracy in favor of fascism or any other kind of non-democratic regime. In academic and political discourse, it was argued that implementing institutions of "militant democracy" would be instrumental for achieving that goal (the idea is often attributed to Loewenstein 1937a, b). The popularity of such ideas in post-war Germany is not surprising, having experienced the rise of the Nazi party through regular democratic processes, only for the national socialists swiftly to dismantle all democratic checks on their power. Today, would-be autocrats often use and shape the rules of the constitution to get rid of democracy. Examples abound: Recep Erdogan introduced a presidential form of government with vast powers for the chief executive (himself) after declaring a state of emergency. Viktor Orbán, the prime minister of Hungary leveraged a bare majority of the popular vote to pass an entirely new constitution fitted to his personal power aspirations. Hugo Chavez introduced a "Bolivarian constitution" in Venezuela and led his country into political isolation and economic decline (see Grier and Maynard 2016). Constitutional change often has been used by politicians to increase their power and prolong their stay in office. $^{1}$

Here, we ask how constitutions can be designed such that they are less vulnerable to assaults on the rule of law by degrading checks and balances, lowering law- enforcement standards, or diminishing impartiality in enforcing the law. The question presupposes a constitution that is supposed to establish the rule of law in the first place. ${ }^{2}$ Here, we are not concerned with constraining or removing autocrats who already hold extensive power. Instead, we are interested in constitutional design options available to a society that wants to safeguard the implementation of a set of basic rights and of the rule of law more generally, independent of who gets elected to public office. Our focus on de jure constitutional rules ensures that policy makers are able to implement the proposed changes, if they wish to do so.

We propose to refer to any constitutional design feature that aims at safeguarding constitutionalism as "militant constitutionalism" to document its close relationship with the idea of "militant democracy". 3 The two concepts share the aim of preserving elements of the political order, namely democracy and the rule of law, respectively. However, they differ from one another in a number of important aspects, such as their timing (militant democracy tries to prevent non-democrats from acquiring power, whereas militant

\footnotetext{
1 Kimenyi and Shughart (2008), e.g., discuss the case of Kenya's constitutional referendum in 2005.

2 The rule of law and democracy can exist independently of each other. A would-be autocrat could damage the rule of law while leaving formal democracy intact, and vice versa. Although the two concepts should be distinguished, their realization often coincides in practice (Gutmann and Voigt 2018; Mukand and Rodrik 2020; Voigt 2012).

3 We cannot take credit for inventing the term "militant constitutionalism" as such. It has been used in the academic literature by a number of scholars (most recently by Sajó 2019), but has not yet gained prominence in public discourse.
} 
constitutionalism tries to contain the damage even if enemies of the rule of law have acquired political power), the actors charged with their implementation (the government versus actors well beyond the government), and the means employed to reach their goal (bans on extreme parties, media accountability, as well as limits on the freedom of assembly and protecting the constitution from self-serving amendments).

This article relates directly to the research program pursued by James M. Buchanan, who adopted an economic approach to analyze constitutional choice. Here, we try to determine what constitutional constraints members of a society could agree on to bind politicians who are interested in exploiting public office for their own advantage. Proposing ways in which constitutions can be designed such that they offer reliable protection from would-be autocrats may sound like a lofty idea. We make things concrete by not only proposing a number of design features that are likely to make a constitution more resilient to would-be autocrats, but also by subjecting the proposed measures to an empirical test to see whether they made constitutions more resilient in the past.

We find only limited empirical evidence for constitutional rules being systematically able to prevent politicians from undermining their country's constitutional orders. That finding seems to vindicate one of the basic assumptions underlying Loewenstein's (1937a, b) analysis of the rise of anti-constitutionalists in the 1930s, namely that the best antidote is a strong democratic tradition.

The remainder of the article is structured as follows: In the next section, we briefly explicate the concept of militant democracy. Section 3 serves to present our version of the concept of militant constitutionalism. In Sect. 4, we try to evaluate some effects of militant constitutionalism empirically. Section 5 offers conclusions and raises some open questions.

\section{Militant democracy}

Today, Karl Loewenstein and militant democracy frequently are spoken of in the same breath. As the best-known proponent of a stream of thought that was very pertinent in the 1930s in Germany, Loewenstein sought to find an institutional design that could protect parliamentary democracy from its enemies. ${ }^{4}$ Since Loewenstein and militant democracy are so closely connected, we focus on his works to describe the main elements of the concept. In two articles that appeared under the title "Militant Democracy and Fundamental Rights" in the American Political Science Review, Loewenstein (1937a, b) describes fascism as an international movement, gives an account of how some European democracies have turned militant, and finishes with a summary of anti-fascist legislation. Loewenstein did not introduce militant democracy as a new concept derived from firm theoretical reasoning but developed it rather in an inductive process based on a summary of various measures European governments had taken to prevent fascist movements from seizing power. Loewenstein, however, systematically evaluates and endorses some of the measures he describes.

\footnotetext{
${ }^{4}$ Hacke (2018, pp. 246ff.) mentions others, such as Weltsch, Astrow, Bonn, Rosenberg, but also Thomas Mann. Some of the scholars who would later become the "Freiburg school" also participated actively in those discussions. In an article that first appeared in 1933, Wilhelm Röpke (1962) coined the term "illiberal democracy". In an address delivered in 1929, Alexander Rüstow first analyzes the main problem of the Weimar Republic, which he identifies as irresponsibility. He then proceeds to discuss four possible escape routes. Different from many observers at the time, he does not want to bestow more competencies on the president, but, rather, on the chancellor. In the Denkschrift "Politische Gemeinschaftsordnung" of what is today known as the Freiburger Bonhoeffer Kreis, the authors seem to endorse a number of measures proposed by Loewenstein, such as limits on the freedom of speech, assembly, and the media.
} 
The two best-known measures identified by Loewenstein are prohibiting extreme parties and restricting the freedom of assembly. Others are bans on the formation of para-military units, precautions against the illicit use of firearms and other weapons, making editors of newspapers responsible for reports deemed to be "seditious propaganda", measures against incitement to violence or hatred against population groups, the exclusion of people with extremist leanings from public administration, and the creation of a political police that is to control anti-democratic and anti-constitutional activities (Loewenstein 1937b).

Whereas Loewenstein (1937b, p. 645) endorses inhibiting subversive movements altogether ("the most comprehensive and effective measure against fascism"), he is more hesitant with regard to other measures: "Perhaps the thorniest problem of democratic states still upholding fundamental rights is that of curbing the freedom of public opinion, speech, and press in order to check the unlawful use thereof by revolutionary and subversive propaganda" (ibid., p. 652). ${ }^{5}$

The notion of militant democracy is not only firmly rooted in the German constitution and its subsequent interpretation by the Federal Constitutional Court, ${ }^{6}$ it also has experienced a revival in recent years among political scientists and legal scholars on both sides of the Atlantic. ${ }^{7}$ Capoccia (2013) observes that reflections on militant democracy in the United States deviate systematically from those in Europe, as Americans are much more critical of restrictions on the freedom of speech.

Today, some of Loewenstein's proposals appear outdated and inadequate. Capoccia (2013) counts three strategies underlying the various proposals: (a) concentrate power in the executive, (b) distinguish emergency powers from powers granted in normal times, and (c) pass ad hoc legislation to restrict rights of expression, participation, and assembly. Those strategies are supposed to prevent fascist movements from exploiting democratic freedoms to undermine democracy, but all three strategies appear at least debatable. Relying on emergency powers and concentrating powers in the executive often amounts to the same thing, and both strategies have been misused frequently (recent states of emergency in both Turkey and Venezuela come to mind). ${ }^{8}$ Restricting basic rights also can be very costly (see, e.g., Blume and Voigt 2007).

Most debates about militant democracy have focused on conceptual and, in particular, normative issues, such as whether it is paradoxical to be intolerant of the intolerant. ${ }^{9}$ Some

\footnotetext{
5 It seems important to add that Loewenstein believed "democratic tradition" to be an important factor in fighting fascism. In an earlier article, he evaluates the prospects of virtually all European countries to withstand fascism and refers to democratic tradition as an important factor time and again. His comments about Great Britain are a good example: "In no country do better prerequisites for a successful stand against fascist doctrine and practice exist than in Great Britain. Two factors contribute to the expectation that England will be immune from fascism. One is the time-honored acceptance of democratic ideals and institutions in the country in which free government originated" (Lowenstein 1935, p. 776).

6 Examples are articles 79(3), 21(2), 9(2), 18, and 20(4) of the Grundgesetz. Below, we argue that the list does not capture the full relevance of the concept for the German constitution.

7 Kirshner (2014) is a recent exercise in "the ethics of combatting political extremism.".

8 Bjørnskov and Voigt $(2018,2020)$ analyze empirically the reasons underlying declarations of states of emergency.

9 The paradox was introduced by Popper (1944). In the notes to Chapter 7 of the first volume of that work, he writes: "Less well known is the paradox of tolerance: Unlimited tolerance must lead to the disappearance of tolerance. If we extend unlimited tolerance even to those who are intolerant, if we are not prepared to defend a tolerant society against the onslaught of the intolerant, then the tolerant will be destroyed, and tolerance with them." Both Müller (2016) and Wagrandl (2018) argue that with an adequate concept of tolerance, the ostensible paradox disappears.
} 
commentators have criticized the notion of militant democracy for its lack of a precise theoretical foundation, and then gone on to provide one (Müller 2012 supplies a concise history of the concept). Given the slightly outdated and almost naïve appearance of many of the policy measures with which militant democracy is associated, we propose to focus instead on the question whether a constitution can be written in such a way that it is more likely to withstand undermining by would-be autocrats and able to safeguard the rule of law under such circumstances.

\section{Militant constitutionalism}

Above, we argue that many would-be autocrats may want to change the constitution to further their particularistic goals. In this section, we discuss how constitutions can be designed to withstand opportunistic reforms and infringements of the rule of law. As already noted in the introduction, we propose calling such a set of design features militant constitutionalism.

In this section, we focus on possible means of protecting constitutions from would-be autocrats. We assume that a constitution can be distinguished from statutory law by the requirement that formal changes must be approved by a supermajority. We are not concerned with other questions that are relevant to constitutional design, such as the effects of constitutional rules on a society's growth prospects, the distribution of wealth and access to public offices (on those questions, see Gutmann and Voigt 2021a; Voigt 2020). Put differently, we are not considering potentially competing goals, freeing us from the necessity of analyzing complicated tradeoffs.

We begin by discussing the potential role of (1) constitutional amendment rules. That discussion is followed by some proposals regarding (2) the form of government as well as (3) the electoral system. The discussion of (4) the separation of powers widely conceived includes the roles of the administration, the judiciary, and of other non-majoritarian institutions. Before finishing the section with (6) a wide-ranging procedural proposal, we discuss (5) ways in which non-state actors, such as NGOs and the media, could be protected by the constitution against would-be autocrats.

\subsection{Constitutional amendment}

The German constitution's article 79(3) prohibits amending articles 1 and 20 of the constitution. ${ }^{10}$ Such eternity or unamendability clauses have been included in quite a number of constitutions (Albert and Oder 2018 includes various contributions on the topic). Trying to change either those two articles or the articles they are protecting would be an obvious breach of the constitution and should provoke considerable opposition.

Erecting barriers to constitutional change might sound like a panacea to the challenges described above. However, trying to protect the entire constitution by making constitutional change very difficult could provoke one of two unintended consequences. The constitution might be replaced in its entirety, because such a change does not have to comply with

\footnotetext{
10 Article 1 introduces the basic rights provisions of the constitution and establishes that the dignity of man is inviolable. Article 20 establishes that the federal republic is a democratic and social federal state. The two articles are thus central to two fundamental provisions of the German constitution.
} 
formal amendment rules (Landau and Dixon 2015 analyze the substitutability of amendment and replacement), or the constitution might lose its legitimacy and could then simply not be complied with (see Gavison 2002; Contiades and Fotiadou 2013). Accordingly, one should optimize - and not maximize - the difficulty of amending constitutions. That can mean a number of things: Unamendability clauses should be attached to only a few constitutional provisions deemed to be indispensable for maintaining the rule of law. Since the world undergoes continual change, making too many articles unamendable could provoke one of the two unintended consequences just sketched. We, therefore, propose to include an emergency proviso in unamendability clauses, e.g., making them amendable, but only by unanimous agreement in the legislature.

Many gradations exist between unamendability and the standard procedure for amending constitutions. If, say, in a bicameral system a two-thirds majority is needed in both houses, one could make the amendment of specific clauses more difficult by requiring a three-quarters majority or more. Those ideas are, of course, inspired by Buchanan and Tullock (1962).

Would-be autocrats often exploit times of crisis to seek support for sweeping constitutional change, which is then agreed upon in the heat of the moment. Some constitutional amendment procedures avoid that problem, for example, by prescribing parliamentary action in two consecutive legislative periods. In countries that adopt such cooling-off rules (most of them are Scandinavian), parliamentary elections therefore also function as referendums on proposed constitutional amendments. Such an institutional design induces rational reflection on proposed constitutional changes. However, situations arise in which constitutions need to be amended faster. We propose that cooling-off rules can be overruled by more inclusive supermajorities, such as $90 \%$ of the respective chambers.

Situations in which public sentiment supports swift constitutional change may include natural disasters and domestic conflicts. Such events often are dealt with in the short run by declaring states of emergency. After experiencing disasters, many citizens willingly cede additional power to the executive branch and would-be autocrats frequently have taken advantage of that willingness by changing the constitution to expand their powers. ${ }^{11}$ One way of reducing the likelihood of such abuses is to prohibit constitutional change during or in the direct aftermath of a state of emergency.

\subsection{Form of government}

Compared to prime ministers, who can be voted out of office at any time by a parliamentary vote of no confidence, presidents are more insulated, as their survival in office does not depend on parliamentary support. Would-be autocrats should, hence, prefer governing a presidential democracy over a parliamentary one. Anecdotal evidence supports that conjecture. Just witness the changes to the Turkish constitution by Recep Erdogan's Justice and Development Party (AKP). Some evidence shows that presidential systems are more susceptible to constitutional non-compliance than parliamentary ones (Svolik 2015). ${ }^{12}$

\footnotetext{
11 As could be witnessed in 2017 Turkey, when the form of government was changed from parliamentary to presidential during a state of emergency.

12 Identifying presidential systems as causing non-compliance is, however, challenging because the form of government is chosen endogenously chosen and not randomly across the globe (Cheibub 2007).
} 
A straightforward conclusion based on those observations would be to prescribe parliamentary, rather than presidential democratic systems and maybe even to make that part of the constitution unamendable. However, if we assume that some societies prefer to have presidential systems, that recommendation raises the question whether constitutional rules could improve constitutional compliance under presidential forms of government.

\subsubsection{Term limits}

Heads of government who legally can remain in power permanently have stronger incentives to renege on constitutional constraints than those who face constitutional term limits. Many would-be autocrats start out complying with the constitution, only to ignore or change it during subsequent terms of office. Obvious examples are the first terms of Turkey's Recep Erdogan or Russia's Vladimir Putin. Term limits thus might serve an important function in sustaining compliance with the constitution. ${ }^{13}$

Experience shows that not all term limits will be effective (Ginsburg et al. 2011). First, presidents wishing another term may try to change the constitution. An unamendability clause might prevent that from happening. In addition, the precise wording of the clause is key: Do "two terms" mean two consecutive terms, or two terms in total? After having been president for two consecutive terms, Vladimir Putin transferred himself to the office of prime minister, only to return to the office of president in the next election. ${ }^{14}$

\subsubsection{Executive decrees}

While in office, presidents frequently circumvent established law-making procedures (i.e., laws being passed by parliament) by resorting to alternative means, such as executive orders or decrees. Some commentators see executive decree power as a solution to political gridlock. That justification, however, is not entirely convincing: the insulation of the president from parliament undermines the incentives for the president and parliament to compromise.

Many cases can be identified in which executive decree power has been used to expand the powers of the president (see Carey and Shugart 1998 for case studies). ${ }^{15}$ It seems that decree powers that do not require parliamentary support are most dangerous because they may effectively transform the president into a temporary dictator. It would seem to be advisable to limit the power of the president by giving the legislature the right to annul any decree and make all decrees subject to sunset clauses, implying that they automatically cease to have force after some time.

\footnotetext{
13 As a downside, they may motivate opportunistic behavior during an incumbent's final term. This moral hazard can be mitigated, for example, by the incumbent being accountable to a programmatic party whose leaders are interested in winning future elections (Cruz and Keefer 2015; see also Brennan and Kliemt 1994).

14 Empirically, we find term limits only for presidents. It might be worthwhile thinking about term limits for heads of parliamentary governments, too. On the one hand, they can be kicked out of office by a parliamentary majority at any time. On the other hand, they might develop a deeply rooted network of political supporters over time, giving them more leeway in misusing their offices.

15 Rubio and Goretti (1998, p. 33) report that between 1853 and 1989 approximately 25 "necessity and urgency decrees" were issued by Argentine presidents. But in the five years between July 1989 and August 1994 alone, President Menem issued 336 such decrees.
} 


\subsubsection{Right to pardon}

The right to pardon appears to be a remnant from absolutism. In many countries, it is the prerogative of the head of state. If it is (mis-)used to pardon government officials or relatives, the rule of law is easily undermined. Nevertheless, reasons can be found for upholding the institution of pardon in general-wrongful convictions come to mind, but it appears sensible to introduce at least something akin to what is called bias or prejudice in judicial procedure. If close family ties or professional relationships exist between the president and a convict, the right to pardon should be suspended.

\subsubsection{Separation of powers in presidential systems}

It has been argued many times that the presidential form of government secures a clearer separation of powers, because presidents are more insulated from parliament than are prime ministers (e.g., Persson et al. 1997). Whereas a prime minister needs to be supported continuously by a parliamentary majority to stay in office, a president is independent of parliamentary majorities.

That view, however, appears to have been influenced heavily by the US experience. In other countries, presidents have been able to make parliaments their faithful servants, i.e., they have dismantled the separation of powers. Prempeh (2008) offers numerous examples of how African presidents manage to secure legislative approval of their policies. ${ }^{16}$ One way to ensure a stricter separation between the executive and legislative branches would be to force members of the legislature to resign from parliament as soon as they accept a position in government.

\subsection{Electoral system}

In some countries, constitutional amendments are politically "cheap" because of the electoral system. In Hungary, the Fidesz party won slightly more than $50 \%$ of the popular vote in the 2011 election, which the electoral system translated into a two-thirds majority in parliament-enough to pass a new constitution. The Hungarian example demonstrates that the difficulty of amending a constitution also is determined by the electoral system. In theory, some $25 \%$ of the popular vote can be sufficient to secure a parliamentary majority in a firstpast-the-post system (Buchanan and Tullock 1962) and a two-thirds majority in parliament

\footnotetext{
${ }^{16}$ One way is to offer lucrative jobs or buy the support of legislators. Prempeh $(2008$, p. 116) gives an example from Zambia, where President Chiluba appointed nearly half of all legislators to ministerial positions. Furthermore, parties sometimes have the power to expel legislators from parliament who oppose the president. That power was exercised in Zambia in 2001, when the ruling party expelled 22 legislators for their opposition to President Chiluba's attempt to secure a third term in office. Sometimes, the constitution even allows for such expulsion of parliamentarians explicitly. Article 77(1) of Sierra Leone's constitution, for example, states that a legislator must vacate his seat "if by his conduct in Parliament by sitting and voting with members of a different party, the Speaker is satisfied after consultation with the Leader of that Member's party that the Member is no longer a member of the political party under whose symbol he was elected to Parliament". Van Cranenburgh (2009) reports that in many African countries, the president may nominate some members of parliament for cabinet positions; their numbers might be quite substantial, such as in Kenya and Zimbabwe. In the first decade of the new millennium, the share of members of parliament in Namibia who held cabinet positions went as high as $60 \%$. The prospect of securing a government job in the future will not only make cabinet members less critical of the government, but also influence parliamentarians who hope to secure such positions in the future.
} 
is attainable with a far smaller share of the popular vote. Under proportional representation, a two-thirds majority in parliament presupposes a two-thirds majority among voters.

The considerations above speak in favor of proportional representation. However, suppose that a society prefers to have single member districts in which parliamentarians are elected based on a first-past-the-post system. At least two ideas come to mind on how the imbalance between popular vote and parliamentary seat shares could be reduced. First, electoral systems no longer should allocate bonus seats to particular parties (as in the case of Italy). Second, so-called "overhang mandates" (used especially in Germany) could be introduced that could limit the imbalance to some pre-determined maximum. ${ }^{17}$

Electoral rules enjoy constitutional status in only one out of five countries (Elkins et al. 2009). Once a country has agreed on a fair electoral system in the sense just outlined, one means of safeguarding that system would be to fix it in the constitution.

\subsubsection{Redistricting}

The electoral system not only comprises electoral rules, but also the sizes of the voting districts and their exact delineations. Would-be autocrats (and not only them) often have redrawn district boundaries to raise their parliamentary seat shares. Levitsky and Ziblatt (2018) give Malaysia as an example. Only half of the country's population consists of ethnic Malayans, but the districts were structured such that in $70 \%$ of the districts, Malayans had clear majorities. Since it is necessary to redraw district lines because of demographic change, some mechanism must be provided for doing so. To avoid gerrymandering, it seems most reasonable to install an electoral commission whose independence is constitutionally protected and that has the competence to redraw voting districts after every census (see, e.g., Aaken 2009; Ham and Garnett 2019). ${ }^{18}$

\subsection{The separation of powers}

It is asserted frequently that the first steps of democratically elected would-be autocrats on their way to free themselves from constitutional constraints are to weaken judicial independence, restrict media freedom, and constrain the operations of a civil society. ${ }^{19}$

\subsubsection{Judicial independence}

Poland's conservative government recently lowered the retirement ages of judges and applied the new legislation also to sitting judges, pensioning many of them off. That action

\footnotetext{
17 Overhang mandates are additional seats awarded to a party under Germany's mixed member proportional system. They serve to ensure that a party's share of the nationwide party votes is equal to its share of seats in parliament, even if it won fewer seats from representing individual constituencies.

18 Quarrels about redistricting hardly are relevant in proportional rule electoral systems because the number of seats of a party should always be proportional to the vote share it secures in the election, provided that the vote share exceeds some minimal threshold.

${ }^{19}$ Indeed, empirical evidence suggests that reductions in freedom of the media and civil society organizations both are determinants of the vibrancies of electoral democracies, as well as the executive branch's compliance with the constitution (Gutmann and Voigt 2021c).
} 
gave the government the opportunity to staff the courts with new, more compliant judges. ${ }^{20}$ Similar measures have been taken by various would-be autocrats and Hungary's Viktor Orbán is just one example. It would seem that protecting the independence of judges to ensure compliance with the constitution could be achieved easily by introducing a constitutional protection of judicial independence that is difficult to avoid.

However, two caveats have to be considered. The first concerns the assumption that strong de jure judicial independence translates into strong de facto judicial independence. That assumption has been challenged with regard to both the Americas and Europe (Gutmann and Voigt 2020, 2021b). The second caveat concerns the insight of Ginsburg and Huq (2018, p. 174) that the "central role played by the courts can perversely raise the stakes in political battles over who controls the courts." Those objections notwithstanding, it seems sensible to codify the appointment procedures and tenures of judges in the constitution, and to make changing those rules difficult. ${ }^{21}$

\subsubsection{Other non-majoritarian institutions}

In most countries, the judiciary is a "non-majoritarian institution" in the sense that its members are not elected by popular vote but are appointed by some non-majoritarian procedure. Over the past few decades, such non-majoritarian institutions not only have been important topics of debate in academic discourse on improving the quality of governance, they also have engaged controversy in the real world. Just witness discussions of central bank independence in many corners of the globe. ${ }^{22}$ Discourse on non-majoritarian institutions encapsulates very diverse organizations beyond the judiciary, ranging from independent regulatory bodies (for telecommunications, energy, banking, competition, and so on) to central banks, supreme audit institutions, statistical offices, ombudspersons, and independent election commissions. All such institutions constrain, at least ostensibly, the discretionary leeway of governments, implying that large numbers of them should reduce the damage that would-be autocrats can do in the short run. A problem arises, however: Governments themselves frequently have authority to appoint the heads of these agencies. Levitsky and Ziblatt (2018) point out that democratically elected would-be autocrats will try to control as many non-majoritarian institutions as possible. As an example, they point to Hungary's Victor Orbán who did that for prosecutors, supreme auditors, the ombudsperson, the statistical agency, and the constitutional court.

Here are some suggestions for how the danger of non-majoritarian institutions being dismantled can be reduced. Most of them already have been applied in some countries to the judiciary. (1) Make appointment of the heads of the organization depend on a parliamentary supermajority. One also can think of more fine-grained schemes allocating the right to nominate officials to different actors. ${ }^{23}$ (2) Guarantee secure tenures in office to the heads of such agencies. (3) Limit the heads of some of the agencies to one term in office

\footnotetext{
${ }^{20}$ On October 19, 2018, the European Court of Justice decided that the underlying legislation was incompatible with EU law and had to be suspended. Retired judges must be allowed to resume their office (C-619/18).

21 Pari passu, the same also holds for the independence of prosecutors (see Aaken et al. 2010; Gutmann and Voigt 2019).

22 De Haan and Eijffinger (2019) is an up-to-date survey of the debate on the independence of central banks.

${ }^{23}$ Federal judges in Germany are appointed by a Richterwahlausschu $\beta$ that works along those lines. In most of the German states, similar committees exist for the appointment of judges.
} 
with no opportunity for renewal. The prospect of being reappointed after the end of one's term reduces the independence of agency heads, because they are likely to accommodate the preferences of those who have the competence to reappoint them. (4) Establish fixed terms. Justices of the US Supreme Court are appointed for life, as are all other federal judges. A would-be autocrat, who gets to appoint some young judges, can influence the court for many decades. Fixed terms thus seem to be preferable to lifetime terms. However, given that judges accumulate human capital on the bench, the terms should not be too short either.

\subsubsection{Administration}

On the one hand, policy administrators are supposed to be loyal agents of the government. On the other hand, they are said to be self-interested. It appears to be key to good governance that the public administration behaves within the confines of the constitution as well as the general rules that define the activities of the bureaucracy and its relationship with government. Such rules likewise should limit the government's direct influence on the bureaucracy.

Bureaucrats can be thought of as monitors who constrain governmental discretion. In Germany, for example, all civil servants are made overseers of the constitution by what is called "the duty to remonstrate" (Remonstrationspflicht). If a civil servant receives an order from his superior that he believes violates the law, he is duty-bound to let his superior know. Should the superior insist on the order's execution, the civil servant must turn to the superior of his superior. Only if that person also insists that the order be executed does the civil servant have to carry it out. At least in principle, that process seems to be a sensible mechanism for ensuring compliance with the constitution.

A similar, but less far-reaching effect is achieved by whistleblower protection, thereby safeguarding public-sector employees who disclose sensitive information without making the release of such information a duty. Ideally, a Remonstrationspflicht should be combined with protection for whistleblowers. ${ }^{24}$

\subsection{Power to the people}

At the end of the day, governmental compliance with the constitution might well depend on active advocacy by ordinary citizens. A constitutionalized right to resist the government if it violates the constitution may facilitate civil society engagement in support of constitutional compliance. Ginsburg et al. (2013) not only includes a comprehensive overview of constitutionalized resistance clauses, but also analysis of the determinants of their inclusion in a constitution. Ginsburg and his coauthors report that many constitutions include not only a right, but even a duty to resist, which is traced back intellectually to John Locke and Thomas Jefferson. Yet, it is unclear what effects such constitutional provisions have.

\footnotetext{
${ }^{24}$ Whistleblower protection should, of course, be limited to cases where a reasonable person could assume that the constitution has been violated. Moreover, national security should be considered to the extent possible in designing the formal procedures for whistleblowing.
} 


\subsection{Automatic triggers?}

When a would-be autocrat tries to impair the independence of any of the actors mentioned so far, it is important to know who has the right - and possibly also the duty - to take steps against such actions. The constitution of Honduras, for example, contains an article aimed at reducing the risk that the presidential term limit contained in the constitution could ever be amended. The article stipulates that any president who proposes to extend his or her constitutionally mandated term limit will be removed from office immediately (which happened to President Zelaya in 2009). It is tempting to think of a version of that clause based on which any member of the executive branch who proposes a reduction in media freedom, judicial independence, the liberties of civil society organizations, or something along the same lines automatically would lose office. Yet, many details need to be addressed: Who is to decide that the officeholder not only discussed the pros and cons of a particular institution publicly, but also proposed to change the law formally? How can misuse of such a powerful clause be prevented? On what grounds can the prohibition of deliberation ever be justified?

Until now, the various design features have been presented one after another. But they are, of course, interdependent. Although each proposal can be implemented on its own, we suggest that many of them may act as complements rather than substitutes (similar to what has been argued by Melton and Ginsburg 2014).

Furthermore, de facto judicial independence may be a necessary condition for militant constitutionalism to be successful. Constitutional assemblies can draft wonderful constitutions with all the features for which one could possibly wish, but unless those features are implemented, the constitutional document becomes dead letter rather soon. An independent judiciary might be needed to enforce the constitution vis-à-vis the chief executive. ${ }^{25}$ That is more likely to be the case for individual rights than for the rules concerning the organization of the state, which are more likely to be self-enforcing.

Regarding desirable features of the constitution, we argue that the combination of a parliamentary form of government and proportional representation is least prone to noncompliance with the constitution. ${ }^{26}$ But we take explicitly into account that the presidential form of government may be preferred in some countries over the parliamentary one; firstpast-the-post elections likewise may be preferred to proportional representation. Regarding the form of government, restricting unilateral executive-branch decrees and the right to pardon should be more important under a presidential system. A parallel consideration refers to the electoral system: Under first-past-the-post voting procedures, restrictive rules regarding redistricting are desirable, whereas the same restrictions are close to irrelevant with proportional representation. A presidential system and a majoritarian electoral system might be less politically risky, if the elected politicians face a strong and independent judiciary as a veto player.

\footnotetext{
${ }^{25}$ Keep in mind that de facto judicial independence is of the essence. For the realization of strong de facto judicial independence, adequate de jure rules are, unfortunately, insufficient.

${ }^{26}$ As noted above, electoral rules rarely are specified in the constitution.
} 


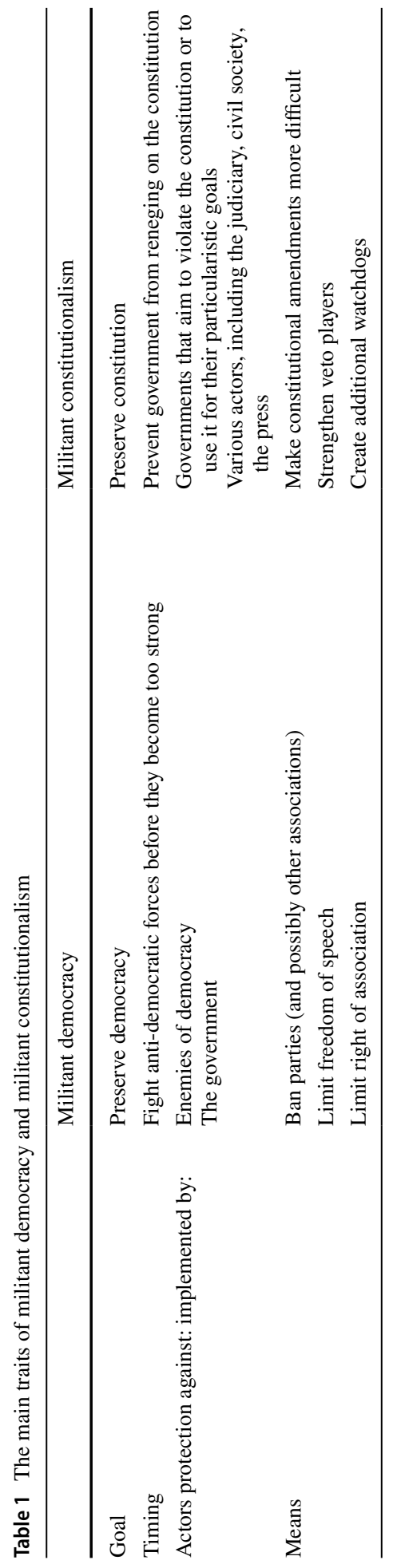




\subsection{Summing up}

In Table 1, we illustrate the commonalities of and differences between militant constitutionalism and militant democracy. The most relevant common element is the attempt of both concepts to preserve the status quo (democracy in the case of militant democracy, the constitutional order in the case of militant constitutionalism). If the country's democracy is protected by the constitution, one could argue that militant constitutionalism is the more encompassing concept. But if we compare the timings of the two concepts, as described in Table 1, it becomes clear that they have a very different focus. Whereas militant democracy aims at preventing anti-democratic forces from rising to power, militant constitutionalism tries to design the constitutional order such that it can withstand challenges by officeholders.

At the end of Sect. 2, the possible misuse of militant democracy was discussed. The possible misuse of militant constitutionalism also should be considered. It is important to spell out explicitly a set of assumptions that have thus far been underlying all considerations, namely that the constitution to be safeguarded not only serves to protect the interests of some powerful elite, that it has been adopted by fair and transparent procedures, and that it is commonly perceived as legitimate. If that is not the case and our proposals for constitutional design are implemented, some of them might help to preserve an illegitimate constitutional order.

Constitutions have been described as rules for making rules. This view would imply that substantive (in contrast to procedural) constraints typically do not belong in the constitution, but rather in statutory law. One can think of many statutory law provisions designed to strengthen constitutional resilience. In recent decades, various parliaments have, for example, passed transparency rules requiring parliamentarians to reveal their sources of income (Aaken and Voigt 2011). One might consider extending those provisions to members of the executive branch.

\section{Gauging the effects of militant constitutionalism empirically}

\subsection{Data and estimation strategy}

In the previous section, we have proposed several design features that can promote constitutional resiliency. We cite empirical evidence where it exists, but some of the proposals never have been implemented and others have not been evaluated with respect to our research question. In this section, we put our notion of militant constitutionalism to an empirical test. As a caveat, we should stress that not only have some of our proposed measures never been implemented, but even if so information on their precise designs often is not available. Our empirical test thus should be understood as a preliminary broad-brush investigation that will have to be followed by more in-depth analyses of the effectiveness of individual constitutional mechanisms that take into account both differences in design (i.e., heterogeneous effects) and in context (i.e., conditional effects).

Our goal is to understand whether various design features that have been implemented in the constitutions of sufficiently many countries can be shown to strengthen political leaders' compliance with the constitution. The Varieties of Democracy (or $\mathrm{V}$-DEM) dataset contains a variable (v2exrescon) that is based on country expert ratings 
and indicates whether members of the executive branch respect the constitution. V-DEM creates a continuous latent variable from expert opinions on a scale running from leading "members of the executive never violate the constitution" to they do so "whenever they want to, without legal consequences" (see Pemstein et al. 2020 for the construction of the latent variable). We invert the indicator such that larger values reflect less compliance with the constitution or a wider de jure-de facto gap (see Law and Versteeg 2013; Gutmann et al. 2021; and Voigt 2021 for the emerging empirical literature on constitutional compliance research).

We assume that the head of government is the most important actor responsible for (non-)compliance with the constitution. Accordingly, our unit of analysis is a "leadership spell", defined as the period during which a head of government holds office without interruption. A prime minister, for example, who stays in office for 12 years before losing an election, constitutes one observation in our dataset. If he held office twice, interrupted by the tenure of another leader, this political leader would be represented by two observations (or two leadership spells) in our dataset. Our dependent variable measures whether and to what extent respect for the constitution deteriorates over the course of a leader's time in office. Therefore, we calculate differences in the level of constitutional compliance from the year before the leader takes office to the year before the leader leaves the post. In other words, the benchmark for a leader's compliance is the compliance level "inherited" from his predecessor; the leader's compliance is measured before the end of the leadership spell in order not to consider the events that caused and followed the leader's removal, such as a military coup. We code any negative change as a zero (i.e., improvements in constitutional compliance are treated as no change in compliance during a leader's term). We do so because our research question is whether constitutional rules can prevent deterioration in constitutional compliance under opportunistic politicians. While constitutional rules also may create favorable conditions for more constitutional compliance over time, that effect is not within the scope of our empirical analysis. By construction, we disregard leadership spells that start and end in the same year, as our data do not allow us to measure changes in constitutional compliance within a given year.

As we have indicated already, not all constitutional rules that we proposed have been adopted in real world constitutions; others are so rare that no systematic data are available on their use. Here, we focus on a list of (0-1) indicator variables to be evaluated as potential safeguards, based on the de jure data collected by Elkins et al. (2009) in their Comparative Constitutions Project:

- Unamendability [unamend] is a binary variable indicating whether any constitutional provision cannot be amended. It is, hence, only a crude proxy for the very detailed proposals spelled out in Sect. 3.

- Term limits for the head of state [hosterml] is a binary variable capturing whether the total number of terms in office for the head of state is limited to two or one.

- Decree power [hosdec]; captures whether or not the head of state can issue decrees unilaterally.

- Pardon [hospard] indicates whether or not the head of state has the power to pardon.

- Judicial Independence [judind] is a binary variable indicating explicit constitutional language declaring independence of the judiciary from other branches of government.

- Right to political parties [partrght] indicates that the constitution specifies the right to form political parties.

- Right to trade union [jointrde] indicates whether the constitution provides the right to form or join trade unions. 
- Freedom of association [assoc] indicates whether the constitution provides freedom of association.

- Freedom of the press [press] identifies constitution provisions guaranteeing press freedom.

- Meritocratic civil service [civil] indicates whether or not the constitution provides for meritocratic recruitment of civil servants.

- Right to overthrow government [overthrw] identifies constitutional provisions empowering citizens under certain conditions to overthrow the government.

Some of the design features proposed earlier cannot be tested, such as constitutional protections for the independence of several non-majoritarian agencies, such as ombudspersons or electoral commissions. Others can be tested only on the basis of rather crude measures of what we have in mind (e.g., unamendability clauses, the effects of which we evaluate broadly by entering a binary variable indicating whether any constitutional provision is exempt from change). Elkins et al.s (2009) indicators are recorded annually at the country level. In a first step, we replace each observation by its one-year lagged value to identify the constitutional rules in place at the beginning, rather than at the end, of the year. Next, we organize them by leadership spells by calculating the means of all country-year observations for those periods. In that way, we account for the average level of constitutional constraints over the course of leadership spells. Alternatively, we enter the constitutional constraints in place before the political leader takes office. Two more indicators of interest come from Bjørnskov and Rode's (2020) regime dataset. The first is a de facto indicator of presidentialism. However, we do not expect de jure and de facto presidentialism to differ much because it seems unlikely that a country's constitution prescribes a presidential form of government, but a parliamentary system is implemented, nor that the reverse is true. The second indicator is a dummy variable for democracy, which helps us to compare presidential democracies with other democracies. The estimated coefficient on the democracy indicator thus captures the effect of a country being democratic per se, whereas the estimated coefficient on presidentialism measures the difference between presidential and other democracies. As with the constitutional indicators, we calculate the means of both over leadership spells to aggregate country-year information at that level.

We control for the extent to which the government respects the constitution at the beginning of each leadership spell, allowing us to take into account possible convergence in constitutional compliance across political leaders. Our empirical approach is based on the conjecture that deteriorations in compliance may be more likely if the level of constitutional compliance is high at the beginning of a leader's term. We also control for the ways in which the leaders assumed office, distinguishing between regular entry, irregular entry (for example, in a coup d'état), and foreign imposition. That information and all other leader characteristics are taken from the Archigos dataset 4.1 (Goemans et al. 2009). Finally, we control for the second order polynomial of the length of the leadership spell in years (i.e., for linear and squared terms) as well as for the number of previous (uninterrupted) leadership spells of the country's current political leader.

Our dataset includes 1,262 leadership spells in 157 countries from 1950 to 2015. Observations on some leadership spells before 1950 are available but owing to concerns about comparability and data quality, we discard leaders who held office in 1949 or earlier. Descriptive statistics are presented in Table 5 in the Appendix. On average, leaders stayed in office for 6.1 consecutive years, with a minimum of two years and a maximum of 48 years (the years in which a leader took office or left it are counted as full years). The longest running political leader in our dataset is King Hussein of Jordan, who reigned from 
1952 until his death in 1999. Only 125 leaders entered office irregularly and another nine were imposed by a foreign country. Interestingly, Hungarian communist János Kádár was the only one of the nine foreign imposed leaders under whom constitutional compliance deteriorated.

The largest deterioration during one leadership spell in our sample occurred under the rule of Juan Velasco Alvarado in Peru between 1968 and 1975. General Velasco was the commander of Peru's armed forces when he seized power in a nonviolent military coup. Subsequently, he was named president and started to nationalize entire industries while ruling in an authoritarian fashion. Political opponents were persecuted, and the media were censored. In 1974, all newspapers were expropriated, and their publishers exiled. Velasco was removed by a military coup in 1975 in the midst of rapid inflation, high unemployment, and severe food shortages. The second largest deterioration in constitutional compliance in a single leadership spell was experienced in Uruguay during the presidency of Juan María Bordaberry. Bordaberry became president in 1972. One year later, he dissolved the general assembly and started to rule by decree. He eventually was ousted by the military in 1976, after having proposed radical constitutional reforms to solidify his power.

\subsection{Empirical results}

Table 2 reports the results of estimating our main model. They and the following results are based on ordinary least squares estimation and country-clustered standard errors, unless specified otherwise. In Column 1, the constitutional constraints are averaged over leadership spells, as explained above. In Column 3, we enter the same constitutional indicators, but we instrument them in a 2 SLS regression with the constitutional rules that were in place before the start of the leadership spell. That procedure accounts for the fact that Column 1's explanatory variables are endogenous to events occurring during leadership spells. Entering lagged constitutional features as instruments makes use of their persistence and evaluates the effects of variation in constitutional provisions in place before leadership spells began. Column 2 reports the reduced form estimates for an instrumental variables regression that replaces the mean values with the constitutional rules in place before the leader took office. Evidently, all three empirical models produce almost identical results.

Let us first take a look at the control variables. Note that a positive and significant coefficient estimate indicates an increase in the de jure-de facto gap (i.e., a reduction in constitutional compliance). Leaders in democracies are, therefore, less likely to undermine respect for the constitution. Leaders who acquire power irregularly, however, are significantly more likely to reduce constitutional compliance during their times in office. In addition, we observe convergence in constitutional compliance across political leaders: reductions in compliance become more likely or sizeable when initial constitutional compliance (i.e., compliance at the beginning of a leadership spell) was higher.

When it comes to our independent variables of interest, the results seem to indicate that constitutional constraints per se are not effective instruments in preventing constitutional backsliding. Most indicators of the constitutional rules we account for are not significantly related to the propensity of constitutional backsliding. One exception is our presidentialism measure. Presidents are more likely than other democratic leaders to reduce compliance with the constitution over the course of their terms in office, as gauged by the positive and significant coefficient on presidentialism. In fact, presidential democracies do not perform differently than nondemocratic countries (based on the sum of the coefficients on presidentialism and democracy, which is not significantly different from zero). That result is very 
much in line with extant empirical evidence that presidential democracies perform poorly with respect to the rule of law (Gutmann and Voigt 2018).

Our second finding concerns the right to form political parties. Against our expectations, constitutional protection of that right is associated with greater risk that the chief executive will undermine compliance with the constitution. While that observation is not consistent with our idea of militant constitutionalism, it can be considered supportive of the concept of militant democracy. As explained above, a core aspect of militant democracy is to ban extremist speech as well as extremist political parties and movements. One interpretation of our result is that a constitutional protection of the right to form parties might be abused by the opponents of liberal democracy, who form political parties and organizations aiming at abolishing these very political freedoms. ${ }^{27}$

Table 3 reports the results of estimating the model in Column 1 of Table 2, but for specific subsamples. On the one hand, we distinguish between low- and high-income countries. On the other hand, we distinguish political leaders who entered office irregularly, e.g., in a coup d'état, from those that entered regularly or were imposed from the outside. Our expectation is that militant constitutionalism might be more effective in countries with higher incomes and for political leaders who entered office through normal constitutional processes.

We find that unamendability of parts of the constitution in high-income countries, indeed, is associated with a lower risk of constitutional backsliding, which is significantly different from its effect in low-income countries. The negative effect of the right to form parties also is significant only in high-income countries, although the difference in effects is not statistically significant. Finally, we find yet another result for high-income countries that is more in line with the arguments of militant democracy than with those of militant constitutionalism. Protecting the freedom of the press constitutionally is associated with greater risk of deteriorating constitutional compliance during a leadership spell. Again, our results might suggest that such freedoms could be abused by political agitators, so that moderate regulation of extremist media content might be inhibited unduly by an explicit constitutional protection.

The distinction between political leaders who entered office in irregular modes and other political leaders brings to light interesting insights, too. First, after irregular entry, democracy plays a dramatically larger role in preventing constitutional backsliding (the difference being statistically significant). Second, and more important for our research question, constitutionally guaranteed executive decree power is associated with more constitutional backsliding, but only if the political leader came into office irregularly (the difference in effects being statistically significant). That result is very much in line with the concept of militant constitutionalism. Our findings indicate that decree power indeed can be abused by political leaders who seek to undermine the rule of law.

In Table 4, we report empirical estimates based on two additional sample splits. First, we distinguish countries that have been democratic for at least ten years at the beginning of a leader's term from those that were not. Second, we distinguish countries

\footnotetext{
27 Although the correlation matrix in Table 6 in the Appendix indicates that none of our constitutional indicators are strongly correlated pairwise, we have estimated additional models that include only one constitutional trait identified by Elkins et al. (2009) at a time, along with our other control variables. We continue to find that only presidentialism and the right to form political parties are significant.
} 
Table 2 Main model

\begin{tabular}{|c|c|c|c|}
\hline & (1) & (2) & (3) \\
\hline & Mean & Lag & IV \\
\hline \multirow[t]{2}{*}{ Initial noncompliance } & $-0.071^{* * *}$ & $-0.071^{* * *}$ & $-0.072^{* * *}$ \\
\hline & $(0.013)$ & $(0.012)$ & $(0.013)$ \\
\hline \multirow[t]{2}{*}{ Previous terms in office } & -0.001 & -0.004 & -0.003 \\
\hline & $(0.014)$ & $(0.014)$ & $(0.014)$ \\
\hline \multirow[t]{2}{*}{ Irregular entry } & $0.378^{* * *}$ & $0.397^{* * *}$ & $0.401^{* * *}$ \\
\hline & $(0.070)$ & $(0.073)$ & $(0.072)$ \\
\hline \multirow[t]{2}{*}{ Regular entry } & 0.049 & 0.063 & 0.063 \\
\hline & $(0.051)$ & $(0.054)$ & $(0.055)$ \\
\hline \multirow[t]{2}{*}{ Presidential } & $0.099^{* * *}$ & $0.095^{* * *}$ & $0.095^{* * *}$ \\
\hline & $(0.022)$ & $(0.021)$ & $(0.021)$ \\
\hline \multirow[t]{2}{*}{ Democracy } & $-0.125^{* * *}$ & $-0.121^{* * *}$ & $-0.125^{* * *}$ \\
\hline & $(0.033)$ & $(0.033)$ & $(0.034)$ \\
\hline \multirow[t]{2}{*}{ Right to resist } & 0.024 & 0.069 & 0.077 \\
\hline & $(0.053)$ & $(0.058)$ & $(0.064)$ \\
\hline \multirow[t]{2}{*}{ Unamendability } & -0.028 & -0.023 & -0.024 \\
\hline & $(0.023)$ & $(0.023)$ & $(0.024)$ \\
\hline \multirow[t]{2}{*}{ Term limits } & -0.017 & -0.026 & -0.031 \\
\hline & $(0.023)$ & $(0.025)$ & $(0.028)$ \\
\hline \multirow[t]{2}{*}{ Decree power } & 0.037 & 0.019 & 0.022 \\
\hline & $(0.025)$ & $(0.027)$ & $(0.030)$ \\
\hline \multirow[t]{2}{*}{ Right to pardon } & -0.027 & -0.027 & -0.028 \\
\hline & $(0.026)$ & $(0.030)$ & $(0.034)$ \\
\hline \multirow[t]{2}{*}{ Judicial independence } & -0.018 & -0.032 & -0.034 \\
\hline & $(0.026)$ & $(0.031)$ & $(0.033)$ \\
\hline \multirow[t]{2}{*}{ Right to parties } & $0.051^{*}$ & $0.083^{* *}$ & $0.091^{* *}$ \\
\hline & $(0.024)$ & $(0.026)$ & $(0.029)$ \\
\hline \multirow[t]{2}{*}{ Right to NGOs } & 0.004 & -0.002 & -0.004 \\
\hline & $(0.024)$ & $(0.025)$ & $(0.027)$ \\
\hline \multirow[t]{2}{*}{ Right to unions } & 0.020 & 0.006 & 0.008 \\
\hline & $(0.025)$ & $(0.029)$ & $(0.032)$ \\
\hline \multirow[t]{2}{*}{ Press freedom } & 0.032 & 0.041 & 0.045 \\
\hline & $(0.021)$ & $(0.023)$ & $(0.025)$ \\
\hline \multirow[t]{2}{*}{ Right of association } & -0.035 & -0.005 & -0.009 \\
\hline & $(0.034)$ & $(0.039)$ & $(0.046)$ \\
\hline Observations & 1,262 & 1,262 & 1,262 \\
\hline Countries & 157 & 157 & 157 \\
\hline
\end{tabular}

(1/2): OLS regression coefficients with country-clustered standard errors in parentheses, (3): 2SLS-instrumental variable regression coefficients with country-clustered standard errors in parentheses, observations are leadership spells, *: 0.05, **: 0.01, ***: 0.001 
Table 3 Sample split by income/ leader entry

\begin{tabular}{|c|c|c|c|c|}
\hline & (1) & (2) & (3) & (4) \\
\hline & HighInc & LowInc & Irregular & Regular/Imp \\
\hline \multirow{2}{*}{$\begin{array}{l}\text { Initial noncompli- } \\
\text { ance }\end{array}$} & $-0.071^{* *}$ & $-0.089^{* * *}$ & $-0.320^{* * *}$ & $-0.022^{* *}$ \\
\hline & $(0.021)$ & $(0.017)$ & $(0.050)$ & $(0.008)$ \\
\hline \multirow{2}{*}{$\begin{array}{l}\text { Previous terms in } \\
\text { office }\end{array}$} & 0.011 & -0.010 & -0.141 & 0.005 \\
\hline & $(0.021)$ & $(0.019)$ & $(0.100)$ & $(0.011)$ \\
\hline \multirow[t]{2}{*}{ Irregular entry } & $0.606^{*}$ & $0.302^{* * *}$ & & \\
\hline & $(0.232)$ & $(0.073)$ & & \\
\hline \multirow[t]{2}{*}{ Regular entry } & -0.051 & 0.067 & & $0.087^{* * *}$ \\
\hline & $(0.114)$ & $(0.065)$ & & $(0.028)$ \\
\hline \multirow[t]{2}{*}{ Presidential } & $0.123^{* * *}$ & $0.086^{* *}$ & 0.059 & $0.062^{* * *}$ \\
\hline & $(0.035)$ & $(0.029)$ & $(0.159)$ & $(0.018)$ \\
\hline \multirow[t]{2}{*}{ Democracy } & $-0.158^{*}$ & $-0.113^{* *}$ & $-0.514^{* *}$ & $-0.055^{*}$ \\
\hline & $(0.073)$ & $(0.036)$ & $(0.186)$ & $(0.027)$ \\
\hline \multirow[t]{2}{*}{ Right to resist } & 0.157 & -0.044 & -0.125 & 0.016 \\
\hline & $(0.133)$ & $(0.037)$ & $(0.350)$ & $(0.052)$ \\
\hline \multirow[t]{2}{*}{ Unamendability } & $-0.060^{*}$ & -0.004 & -0.178 & -0.009 \\
\hline & $(0.027)$ & $(0.028)$ & $(0.117)$ & $(0.016)$ \\
\hline \multirow[t]{2}{*}{ Term limits } & -0.058 & 0.013 & -0.085 & -0.011 \\
\hline & $(0.030)$ & $(0.031)$ & $(0.136)$ & $(0.017)$ \\
\hline \multirow[t]{2}{*}{ Decree power } & 0.013 & 0.044 & $0.370^{* * *}$ & 0.003 \\
\hline & $(0.032)$ & $(0.030)$ & $(0.129)$ & $(0.021)$ \\
\hline \multirow[t]{2}{*}{ Right to pardon } & 0.002 & -0.038 & -0.197 & $-0.057^{*}$ \\
\hline & $(0.030)$ & $(0.040)$ & $(0.133)$ & $(0.028)$ \\
\hline \multirow{2}{*}{$\begin{array}{l}\text { Judicial independ- } \\
\text { ence }\end{array}$} & -0.037 & 0.024 & -0.342 & 0.006 \\
\hline & $(0.031)$ & $(0.030)$ & $(0.237)$ & $(0.015)$ \\
\hline \multirow[t]{2}{*}{ Right to parties } & $0.072^{*}$ & 0.042 & 0.241 & 0.026 \\
\hline & $(0.030)$ & $(0.033)$ & $(0.147)$ & $(0.016)$ \\
\hline \multirow[t]{2}{*}{ Right to NGOs } & -0.046 & 0.055 & 0.035 & 0.010 \\
\hline & $(0.027)$ & $(0.031)$ & $(0.144)$ & $(0.020)$ \\
\hline \multirow[t]{2}{*}{ Right to unions } & 0.030 & 0.019 & 0.218 & 0.005 \\
\hline & $(0.040)$ & $(0.035)$ & $(0.159)$ & $(0.020)$ \\
\hline \multirow[t]{2}{*}{ Press freedom } & $0.089^{* *}$ & -0.005 & 0.186 & 0.011 \\
\hline & $(0.028)$ & $(0.027)$ & $(0.126)$ & $(0.017)$ \\
\hline \multirow{2}{*}{$\begin{array}{l}\text { Right of associa- } \\
\text { tion }\end{array}$} & -0.077 & -0.073 & -0.235 & -0.002 \\
\hline & $(0.044)$ & $(0.053)$ & $(0.201)$ & $(0.025)$ \\
\hline Observations & 634 & 628 & 142 & 1,120 \\
\hline Countries & 85 & 127 & 65 & 154 \\
\hline
\end{tabular}

OLS regression coefficients with country-clustered standard errors in parentheses, indicators for constitutional rules are mean values for the leadership spell as in Column 1 of Table 2, observations are leadership spells, *: 0.05, **: 0.01, ***: 0.001 
Table 4 Sample split by age of democracy/judicial independence

\begin{tabular}{|c|c|c|c|c|}
\hline & $\begin{array}{l}(1) \\
\text { DAge } 10+\end{array}$ & $\begin{array}{l}(2) \\
\text { DAge 9- }\end{array}$ & $\begin{array}{l}\text { (3) } \\
\text { High JI }\end{array}$ & $\begin{array}{l}\text { (4) } \\
\text { Low JI }\end{array}$ \\
\hline Initial noncompliance & $\begin{array}{l}-0.002 \\
(0.014)\end{array}$ & $\begin{array}{l}-0.104^{* * * *} \\
(0.017)\end{array}$ & $\begin{array}{l}-0.034^{*} \\
(0.015)\end{array}$ & $\begin{array}{l}-0.118^{\text {**** }} \\
(0.021)\end{array}$ \\
\hline Previous terms in office & $\begin{array}{l}0.022 \\
(0.018)\end{array}$ & $\begin{array}{l}-0.016 \\
(0.018)\end{array}$ & $\begin{array}{l}-0.004 \\
(0.013)\end{array}$ & $\begin{array}{l}-0.007 \\
(0.032)\end{array}$ \\
\hline Irregular entry & & $\begin{array}{l}0.345^{* * * *} \\
(0.075)\end{array}$ & & $\begin{array}{l}0.344^{* * * *} \\
(0.077)\end{array}$ \\
\hline Regular entry & $\begin{array}{l}0.091 \\
(0.197)\end{array}$ & $\begin{array}{l}0.000 \\
(0.058)\end{array}$ & $\begin{array}{l}-0.313 \\
(0.158)\end{array}$ & $\begin{array}{l}0.017 \\
(0.062)\end{array}$ \\
\hline Presidential & $\begin{array}{l}0.056^{* *} \\
(0.021)\end{array}$ & $\begin{array}{l}0.119^{* * *} \\
(0.036)\end{array}$ & $\begin{array}{l}0.020 \\
(0.017)\end{array}$ & $\begin{array}{l}0.185^{* * *} \\
(0.046)\end{array}$ \\
\hline Democracy & $\begin{array}{l}-2.257^{*} \\
(0.950)\end{array}$ & $\begin{array}{l}-0.123^{* * * *} \\
(0.035)\end{array}$ & $\begin{array}{l}-0.099 \\
(0.052)\end{array}$ & $\begin{array}{l}-0.097^{*} \\
(0.045)\end{array}$ \\
\hline Right to resist & $\begin{array}{l}0.028 \\
(0.078)\end{array}$ & $\begin{array}{l}0.034 \\
(0.066)\end{array}$ & $\begin{array}{l}0.036 \\
(0.043)\end{array}$ & $\begin{array}{l}-0.019 \\
(0.086)\end{array}$ \\
\hline Unamendability & $\begin{array}{l}0.023 \\
(0.023)\end{array}$ & $\begin{array}{l}-0.027 \\
(0.035)\end{array}$ & $\begin{array}{l}0.004 \\
(0.022)\end{array}$ & $\begin{array}{l}-0.048 \\
(0.036)\end{array}$ \\
\hline Term limits & $\begin{array}{l}0.019 \\
(0.023)\end{array}$ & $\begin{array}{l}-0.042 \\
(0.035)\end{array}$ & $\begin{array}{l}0.011 \\
(0.022)\end{array}$ & $\begin{array}{l}-0.056 \\
(0.042)\end{array}$ \\
\hline Decree power & $\begin{array}{l}-0.019 \\
(0.031)\end{array}$ & $\begin{array}{l}0.074^{*} \\
(0.033)\end{array}$ & $\begin{array}{l}-0.007 \\
(0.023)\end{array}$ & $\begin{array}{l}0.084^{*} \\
(0.037)\end{array}$ \\
\hline Right to pardon & $\begin{array}{l}-0.050 \\
(0.029)\end{array}$ & $\begin{array}{l}-0.024 \\
(0.041)\end{array}$ & $\begin{array}{l}-0.026 \\
(0.022)\end{array}$ & $\begin{array}{l}-0.043 \\
(0.050)\end{array}$ \\
\hline Judicial independence & $\begin{array}{l}-0.025 \\
(0.018)\end{array}$ & $\begin{array}{l}-0.019 \\
(0.043)\end{array}$ & $\begin{array}{l}0.003 \\
(0.019)\end{array}$ & $\begin{array}{l}-0.064 \\
(0.057)\end{array}$ \\
\hline Right to parties & $\begin{array}{l}0.026 \\
(0.023)\end{array}$ & $\begin{array}{l}0.067 \\
(0.035)\end{array}$ & $\begin{array}{l}0.021 \\
(0.021)\end{array}$ & $\begin{array}{l}0.082^{*} \\
(0.039)\end{array}$ \\
\hline Right to NGOs & $\begin{array}{l}-0.008 \\
(0.020)\end{array}$ & $\begin{array}{l}0.017 \\
(0.033)\end{array}$ & $\begin{array}{l}-0.021 \\
(0.027)\end{array}$ & $\begin{array}{l}0.043 \\
(0.040)\end{array}$ \\
\hline Right to unions & $\begin{array}{l}-0.036 \\
(0.027)\end{array}$ & $\begin{array}{l}0.048 \\
(0.035)\end{array}$ & $\begin{array}{l}-0.007 \\
(0.024)\end{array}$ & $\begin{array}{l}0.025 \\
(0.048)\end{array}$ \\
\hline Press freedom & $\begin{array}{l}0.021 \\
(0.018)\end{array}$ & $\begin{array}{l}0.030 \\
(0.031)\end{array}$ & $\begin{array}{l}0.027 \\
(0.018)\end{array}$ & $\begin{array}{l}0.022 \\
(0.038)\end{array}$ \\
\hline Right of association & $\begin{array}{l}0.058 \\
(0.040)\end{array}$ & $\begin{array}{l}-0.110^{*} \\
(0.052)\end{array}$ & $\begin{array}{l}0.020 \\
(0.033)\end{array}$ & $\begin{array}{l}-0.106 \\
(0.071)\end{array}$ \\
\hline Observations & 559 & 703 & 615 & 647 \\
\hline Countries & 89 & 149 & 84 & 118 \\
\hline
\end{tabular}

OLS regression coefficients with country-clustered standard errors in parentheses, indicators for constitutional rules are mean values for the leadership spell as in Column 1 of Table 2, observations are leadership spells, *: 0.05, **: 0.01, ***: 0.001 
with high and low levels of judicial independence. ${ }^{28}$ Our expectation is that constitutional rights will be more effective in constraining the chief executive in established democracies and countries with powerful and independent judiciaries. In contrast, features of state organization that allocate much power to the executive might be less dangerous in the context of an established democracy or if a strong and independent judiciary exists as a veto player.

Indeed, we find that constitutionally entrenched executive decree power is associated with a greater risk of constitutional backsliding, but only in countries that lack an independent judiciary or that have not been democratic for at least a decade, according to the very minimalistic notion of democracy employed by Bjørnskov and Rode (2020). Also, presidentialism seems to be linked to deteriorating constitutional compliance only if an independent judiciary is lacking that could hold the president in check. That result is consistent with the idea that the US model of politics guarantees compliance with the constitution only if the president faces powerful veto players. When that is the case, presidential democracies are not different from other democracies in terms of constitutional compliance.

As a final extension, we split our sample into different continents. The results are reported in Table 7 in the Appendix. We find that Asian countries are the only ones where a right to resist, i.e., a constitutional right to overthrow the government, is associated with a lower likelihood of seeing constitutional compliance deteriorate (the difference being statistically significant).

Taken together, our empirical evidence lends some support to the ideas of both militant democracy and militant constitutionalism. Extensive protections of political parties and media freedom might be abused by political agitators who aim to undermine a liberal constitutional order. At the same time, we find some evidence that making parts of the constitution unamendable and giving citizens the right to overthrow the government may increase constitutional compliance, at least in some settings. What is most important, we find empirical evidence that when political leaders come to power irregularly and when political and legal institutions do not guarantee their accountability, executive decree power can be a dangerous political instrument. The same conclusion applies to presidentialism, which also is dangerous for constitutional compliance, at least if the president does not face a strong and independent judiciary.

\section{Conclusions and outlook}

We have proposed that militant constitutionalism is a design concept for constitutions that can limit the harm inflicted on the rule of law by would-be autocrats. Militant constitutionalism differs from militant democracy, which attempts to keep the enemies of democracy out of any of the branches of government.

We have tried to ascertain the effectiveness of militant constitutionalism by asking whether governments operating under constitutions with some proposed provisions are more likely to maintain respect for the constitution than governments that are free of those constraints. Inter alia, we proposed to make specific constitutional rules unamendable, to

\footnotetext{
${ }^{28}$ The sample is split at a judicial independence level of 0.75 such that the subsamples are of about equal size.
} 
rely on a parliamentary form of government and a proportional electoral system, to ensure the independence of non-majoritarian agencies, and to set incentives for bureaucrats to monitor the behavior of their superiors regarding their compliance with the constitution. To estimate the effects empirically, we rely on the period during which single leaders remain at the helms of government without interruption as our unit of analysis. Although our empirical results lend some support to both the ideas of militant democracy and militant constitutionalism, many constitutional rules could not be shown to contribute to constitutional resilience.

While it is unfortunate that we cannot offer a panacea for designing better constitutions and the effectiveness of many proposed constitutional rules could not be demonstrated empirically, some of our null findings may teach important lessons. (1) Details matter. Many of the indicators of constitutional resilience we evaluated are crude approximations of the concepts we have in mind. Just making any part of the constitution unamendable clearly is different than protecting specific, strategically relevant elements of the constitutional order. (2) Context matters. Our simple empirical model might not be able to capture the complexity of real-world constitutional constraints. Their effectiveness may depend on finer nuances, such as their wording, the country's history, the presence of other constitutional rules, and so on. (3) De jure rules are not enforced automatically. It might be too optimistic to expect that legal texts- "parchment barriers"-alone can safeguard the rule of law (e.g., Voigt and Gutmann 2013). While we have tried to capture different levels of enforcement by studying the effectiveness of militant constitutionalism in various groups of countries, it actually might be necessary to measure de facto institutions to find any effects (see Feld and Voigt 2003; Voigt et al. 2015). The downside of de facto institutions is, of course, that it is far more difficult to bring them into being.

In his work on militant democracy, Loewenstein (1937a, b) conjectures that a long democratic tradition might be the best disinfectant against the rise of anti-democratic politicians. He thus assumed that long experience makes democratic survival more likely. Our finding that countries that have been democratic for at least ten years without interruption are unlikely to suffer from deteriorations in constitutional compliance accord well with his conjecture. However, the possibilities of constraining would-be autocrats by relying on constitutional design seem limited. Future research, therefore, should also study whether extra- or pre-constitutional practice is crucial in sustaining the rule of law: If trust between the government and citizens is sufficiently high, detailed and lengthy constitutional rules might be superfluous. It seems quite plausible that specific constitutional constraints become effective only if they are implemented in a favorable (cultural/informal institutional) environment.

At the end of the day, rules will be complied with only if a sizeable portion of the population cares about them being complied with. If the rule of law meets lukewarm approval or complete disregard by the population, the government might get away with ignoring constitutional constraints, implying that democratic governments would do well to promote an enlightened constitutional culture, such that citizens understand and appreciate the values of their constitutions. The goal would not be to encourage blind or even fanatical trust in a written document that might be centuries old, but to teach the concrete functions of different constitutional clauses from an early age and to discuss their advantages and disadvantages openly in political debate. 


\section{Appendix}

Tables 5, 6 and 7

Table 5 Descriptive statistics

\begin{tabular}{lrlll}
\hline & Mean & SD & Min & Max \\
\hline (1) Constitutional compliance, change & 0.098 & 0.359 & 0 & 3.828 \\
Initial noncompliance & -0.716 & 1.360 & -3.285 & 3.089 \\
Previous terms in office & 0.212 & 0.534 & 0 & 4 \\
Irregular entry & 0.113 & 0.316 & 0 & 1 \\
Regular entry & 0.880 & 0.325 & 0 & 1 \\
Presidential & 0.514 & 0.499 & 0 & 1 \\
Democracy & 0.677 & 0.461 & 0 & 1 \\
(2) Right to resist & 0.048 & 0.209 & 0 & 1 \\
(3) Unamendability & 0.342 & 0.468 & 0 & 1 \\
(4) Term limits & 0.290 & 0.444 & 0 & 1 \\
(5) Decree power & 0.593 & 0.482 & 0 & 1 \\
(6) Right to pardon & 0.840 & 0.358 & 0 & 1 \\
(7) Judicial independence & 0.686 & 0.459 & 0 & 1 \\
(8) Right to parties & 0.462 & 0.490 & 0 & 1 \\
(9) Right to NGOs & 0.214 & 0.404 & 0 & 1 \\
(10) Right to unions & 0.654 & 0.465 & 0 & 1 \\
(11) Press freedom & 0.596 & 0.481 & 0 & 1 \\
(12) Right of association & 0.862 & 0.336 & 0 & 1 \\
Tenure & 6.110 & 5.663 & 2 & 48 \\
\hline
\end{tabular}

Sample as in Table 2

Table 6 Correlation matrix

$\begin{array}{lllllllllll}(1) & (2) & (3) & \text { (4) } & \text { (5) } & \text { (6) } & \text { (7) } & \text { (8) } & \text { (9) } & \text { (10) } & \text { (11) }\end{array}$

(2) .01

(3) $\quad .03 \quad .06$

(4) $\quad .01 \quad .10 \quad .05$

(5) $\quad .05 \quad .05 \quad .16 \quad .02$

$\begin{array}{llllll}\text { (6) } & -.02 & .06 & .10 & .19 & .23\end{array}$

$\begin{array}{lllllll}\text { (7) } & .01 & .07 & .05 & .28 & .17 & .23\end{array}$

$\begin{array}{llllllll}\text { (8) } & .01 & .19 & .22 & .26 & .03 & .14 & . \mathbf{3 8}\end{array}$

(9) $\quad \begin{array}{llllllll}.01 & .00 & .17 & .01 & .21 & .21 & .15 & .18\end{array}$

$\begin{array}{llllllllll}(10) & .02 & .14 & .08 & .25 & .07 & .17 & \mathbf{. 3 8} & \mathbf{. 4 3} & .14\end{array}$

$\begin{array}{lllllllllll}\text { (11) } & .02 & .06 & .14 & .19 & .13 & .16 & .10 & .16 & .14 & .16\end{array}$

$\begin{array}{llllllllllll}\text { (12) } & -.00 & .08 & -.03 & .06 & .25 & .17 & .29 & \mathbf{. 3 3} & .20 & . \mathbf{4 3} & .29\end{array}$

Sample as in Table 2. Numbers correspond to variable names in Table 5 Correlations larger than 0.3 in bold 
Table 7 Sample split by continents

\begin{tabular}{|c|c|c|c|c|}
\hline & $\begin{array}{l}\text { (1) } \\
\text { Africa }\end{array}$ & $\begin{array}{l}\text { (2) } \\
\text { Ameri- } \\
\text { cas }\end{array}$ & $\begin{array}{l}\text { (3) } \\
\text { Asia }\end{array}$ & $\begin{array}{l}\text { (4) } \\
\text { Europe }\end{array}$ \\
\hline Initial noncompliance & $\begin{array}{l}-0.151^{* * *} \\
(0.040)\end{array}$ & $\begin{array}{l}-0.119^{* * *} \\
(0.032)\end{array}$ & $\begin{array}{l}-0.095^{* * *} \\
(0.027)\end{array}$ & $\begin{array}{l}0.001 \\
(0.013)\end{array}$ \\
\hline $\begin{array}{l}\text { Previous terms in } \\
\text { office }\end{array}$ & $\begin{array}{l}-0.022 \\
(0.084)\end{array}$ & $\begin{array}{l}-0.001 \\
(0.034)\end{array}$ & $\begin{array}{l}-0.032 \\
(0.026)\end{array}$ & $\begin{array}{l}0.018 \\
(0.017)\end{array}$ \\
\hline Irregular entry & $\begin{array}{l}0.130 \\
(0.118)\end{array}$ & $\begin{array}{l}0.267^{*} \\
(0.109)\end{array}$ & $\begin{array}{l}0.341^{\text {**** }} \\
(0.075)\end{array}$ & $\begin{array}{l}0.332^{\text {*** }} \\
(0.042)\end{array}$ \\
\hline Regular entry & $\begin{array}{l}-0.118 \\
(0.073)\end{array}$ & $\begin{array}{l}-0.152 \\
(0.122)\end{array}$ & $\begin{array}{l}-0.007 \\
(0.090)\end{array}$ & $\begin{array}{l}0.016 \\
(0.040)\end{array}$ \\
\hline Presidential & $\begin{array}{l}0.068 \\
(0.115)\end{array}$ & $\begin{array}{l}0.276^{* *} \\
(0.091)\end{array}$ & $\begin{array}{l}0.079^{*} \\
(0.037)\end{array}$ & $\begin{array}{l}0.033 \\
(0.036)\end{array}$ \\
\hline Democracy & $\begin{array}{l}-0.120 \\
(0.079)\end{array}$ & $\begin{array}{l}-0.254^{*} \\
(0.120)\end{array}$ & $\begin{array}{l}-0.134^{*} \\
(0.050)\end{array}$ & $\begin{array}{l}0.023 \\
(0.034)\end{array}$ \\
\hline Right to resist & $\begin{array}{l}-0.006 \\
(0.080)\end{array}$ & $\begin{array}{l}0.151 \\
(0.086)\end{array}$ & $\begin{array}{l}-2.299^{* * * *} \\
(0.620)\end{array}$ & $\begin{array}{l}-0.040 \\
(0.031)\end{array}$ \\
\hline Unamendability & $\begin{array}{l}0.004 \\
(0.076)\end{array}$ & $\begin{array}{l}0.035 \\
(0.057)\end{array}$ & $\begin{array}{l}-0.058 \\
(0.037)\end{array}$ & $\begin{array}{l}0.016 \\
(0.027)\end{array}$ \\
\hline Term limits & $\begin{array}{l}0.022 \\
(0.075)\end{array}$ & $\begin{array}{l}-0.063 \\
(0.078)\end{array}$ & $\begin{array}{l}0.041 \\
(0.045)\end{array}$ & $\begin{array}{l}-0.042 \\
(0.037)\end{array}$ \\
\hline Decree power & $\begin{array}{l}0.082 \\
(0.079)\end{array}$ & $\begin{array}{l}0.014 \\
(0.106)\end{array}$ & $\begin{array}{l}0.065 \\
(0.046)\end{array}$ & $\begin{array}{l}-0.024 \\
(0.020)\end{array}$ \\
\hline Right to pardon & $\begin{array}{l}-0.240 \\
(0.127)\end{array}$ & $\begin{array}{l}-0.005 \\
(0.051)\end{array}$ & $\begin{array}{l}-0.027 \\
(0.060)\end{array}$ & $\begin{array}{l}0.025 \\
(0.027)\end{array}$ \\
\hline Judicial independence & $\begin{array}{l}-0.003 \\
(0.062)\end{array}$ & $\begin{array}{l}-0.049 \\
(0.097)\end{array}$ & $\begin{array}{l}-0.049 \\
(0.041)\end{array}$ & $\begin{array}{l}0.015 \\
(0.021)\end{array}$ \\
\hline Right to parties & $\begin{array}{l}0.021 \\
(0.077)\end{array}$ & $\begin{array}{l}0.029 \\
(0.055)\end{array}$ & $\begin{array}{l}0.147^{* *} \\
(0.043)\end{array}$ & $\begin{array}{l}0.036 \\
(0.030)\end{array}$ \\
\hline Right to NGOs & $\begin{array}{l}0.148 \\
(0.137)\end{array}$ & $\begin{array}{l}-0.025 \\
(0.064)\end{array}$ & $\begin{array}{l}0.001 \\
(0.051)\end{array}$ & $\begin{array}{l}-0.037 \\
(0.032)\end{array}$ \\
\hline Right to unions & $\begin{array}{l}0.158 \\
(0.108)\end{array}$ & $\begin{array}{l}-0.036 \\
(0.117)\end{array}$ & $\begin{array}{l}0.000 \\
(0.036)\end{array}$ & $\begin{array}{l}-0.000 \\
(0.026)\end{array}$ \\
\hline Press freedom & $\begin{array}{l}0.023 \\
(0.085)\end{array}$ & $\begin{array}{l}-0.016 \\
(0.058)\end{array}$ & $\begin{array}{l}0.016 \\
(0.043)\end{array}$ & $\begin{array}{l}0.012 \\
(0.022)\end{array}$ \\
\hline Right of association & $\begin{array}{l}-0.120 \\
(0.148)\end{array}$ & $\begin{array}{l}0.055 \\
(0.176)\end{array}$ & $\begin{array}{l}-0.076 \\
(0.067)\end{array}$ & $\begin{array}{l}0.021 \\
(0.022)\end{array}$ \\
\hline Observations & 190 & 334 & 304 & 381 \\
\hline Countries & 48 & 27 & 41 & 36 \\
\hline
\end{tabular}

OLS regression coefficients with country-clustered standard errors in parentheses, indicators for constitutional rules are mean values for the leadership spell as in Column 1 of Table 2, observations are leadership spells, *: 0.05, **: 0.01, ***: 0.001 
Funding Open Access funding enabled and organized by Projekt DEAL.

Open Access This article is licensed under a Creative Commons Attribution 4.0 International License, which permits use, sharing, adaptation, distribution and reproduction in any medium or format, as long as you give appropriate credit to the original author(s) and the source, provide a link to the Creative Commons licence, and indicate if changes were made. The images or other third party material in this article are included in the article's Creative Commons licence, unless indicated otherwise in a credit line to the material. If material is not included in the article's Creative Commons licence and your intended use is not permitted by statutory regulation or exceeds the permitted use, you will need to obtain permission directly from the copyright holder. To view a copy of this licence, visit http://creativecommons.org/licenses/by/4.0/.

\section{References}

Albert, R., \& Oder, B. E. (2018). An unamendable constitution? Heidelberg et al.: Springer.

Bjørnskov, C., \& Rode, M. (2020). Regime types and regime change: A new dataset on democracy, coups, and political institutions. The Review of International Organizations, 15, 531-551.

Bjørnskov, C., \& Voigt, S. (2018). Why do governments call a state of emergency? On the determinants of using emergency constitutions. European Journal of Political Economy, 54, 110-123.

Bjørnskov, C., \& Voigt, S. (2020). When does terror induce a state of emergency? And what are the effects? Journal of Conflict Resolution, 64(4), 579-613.

Blume, L., \& Voigt, S. (2007). The economic effects of human rights. Kyklos, 60(4), 509-538.

Brennan, G., \& Kliemt, H. (1994). Finite lives and social institutions. Kyklos, 47(4), 551-571.

Buchanan, J., \& Tullock, G. (1962). The calculus of consent: Logical foundations of constitutional democracy. Ann Arbor: University of Michigan Press.

Capoccia, G. (2013). Militant democracy: The institutional bases of democratic self-preservation. Annual Review of Law and Social Science, 9, 207-226.

Carey, J. M., \& Shugart, M. S. (Eds.). (1998). Executive decree authority. Cambridge: Cambridge University Press.

Cheibub, J. A. (2007). Presidentialism, parliamentarism, and democracy. Cambridge: Cambridge University Press.

Contiades, X., \& Fotiadou, A. (2013). Models of constitutional change. In X. Contiades (Ed.), Engineering Constitutional Change: A Comparative Perspective on Europe (pp. 427-478). Canada and the USA: Routledge.

Cruz, C., \& Keefer, P. (2015). Political parties, clientelism, and bureaucratic reform. Comparative Political Studies, 48(14), 1942-1973.

De Haan, J., \& Eijffinger, S. (2019). The politics of central bank independence. In R. Congleton, B. Grofman, \& S. Voigt (Eds.), The Oxford handbook of public choice (Vol. 2, pp. 499-519). Cambridge: Cambridge University Press.

Elkins, Z., Ginsburg, T., \& Melton, J. (2009). The endurance of national constitutions. New York: Cambridge University Press.

Feld, L. P., \& Voigt, S. (2003). Economic growth and judicial independence: Cross-country evidence using a new set of indicators. European Journal of Political Economy, 19(3), 497-527.

Gavison, R. (2002). What belongs in a constitution? Constitutional Political Economy, 13(1), 89-105.

Ginsburg, T., \& Huq, A. Z. (2018). How to save a constitutional democracy. Chicago: University of Chicago Press.

Ginsburg, T., Lansberg-Rodriguez, D., \& Versteeg, M. (2013). When to overthrow your government: The right to resist in the world's constitutions. UCLA Law Review, 60(5), 1184-1261.

Ginsburg, T., Melton, J., \& Elkins, Z. (2011). On the evasion of executive term limits. William and Mary Law Review, 52(6), 1807-1872.

Goemans, H. E., Gleditsch, K. S., \& Chiozza, G. (2009). Introducing Archigos: A dataset of political leaders. Journal of Peace Research, 46(2), 269-283.

Grier, K., \& Maynard, N. (2016). The economic consequences of Hugo Chavez: A synthetic control analysis. Journal of Economic Behavior \& Organization, 125, 1-21.

Gutmann, J., \& Voigt, S. (2018). The rule of law: Measurement and deep roots. European Journal of Political Economy, 54, 68-82.

Gutmann, J., \& Voigt, S. (2019). The independence of prosecutors and government accountability. Supreme Court Economic Review, 27, 1-19. 
Gutmann, J., \& Voigt, S. (2020). Judicial independence in the EU: A puzzle. European Journal of Law and Economics, 49(1), 83-100.

Gutmann, J., \& Voigt, S. (2021a). Quantitative analysis of constitutions Forthcoming. In D. S. Law \& M. Langford (Eds.), Research methods in constitutional law: A handbook. Elgar: Edward.

Gutmann, J., \& Voigt, S. (2021b). On the relationship between de jure and de facto judicial independence: A global puzzle? judicial independence: A global puzzle? Mimeo; Institute of Law \& Economics: University of Hamburg, Germany.

Gutmann, J., \& Voigt, S. (2021c). Predicting democratic backsliding. Mimeo; Institute of Law \& Economics: University of Hamburg, Germany.

Gutmann, J., Metelska-Szaniawska, K., \& Voigt, S. (2021). Constitutional compliance dataset. Mimeo; Institute of Law \& Economics: University of Hamburg, Germany.

Hacke, J. (2018). Existenzkrise der Demokratie: zur politischen Theorie des Liberalismus in der Zwischenkriegszeit. Frankfurt: Suhrkamp Verlag.

Hamilton, A., Madison, J., \& Jay, J. (1788/1961). The Federalist Papers. New York: Mentor.

Kimenyi, M. S., \& Shughart, W. F. (2008). The political economy of constitutional choice: A study of the 2005 Kenyan constitutional referendum. Constitutional Political Economy, 21(1), 1-27.

Kirshner, A. S. (2014). A theory of militant democracy: The ethics of combatting political extremism. Yale: Yale University Press.

Landau, D., \& Dixon, R. (2015). Constraining constitutional change. Wake Forest Law Review, 50(4), 859-890.

Law, D. S., \& Versteeg, M. (2013). Sham constitutions. California Law Review, 101(4), 863-952.

Levitsky, S., \& Ziblatt, D. (2018). How democracies die. Crown.

Loewenstein, K. (1935). Autocracy versus democracy in contemporary Europe. II. American Political Science Review, 29(5), 755-784.

Loewenstein, K. (1937a). Militant democracy and fundamental rights. I. American Political Science Review, 31(3), 417-432.

Loewenstein, K. (1937b). Militant democracy and fundamental rights. II. American Political Science Review, 31(4), 638-658.

Melton, J., \& Ginsburg, T. (2014). Does de jure judicial independence really matter? A reevaluation of explanations for judicial independence. Journal of Law and Courts, 2(2), 187-217.

Mukand, S. W., \& Rodrik, D. (2020). The political economy of liberal democracy. The Economic Journal, $130(627), 765-792$.

Müller, J. W. (2012). Militant democracy. In M. Rosenfeld \& A. Sajó (Eds.), The Oxford Handbook of Comparative Constitutional Law. Oxford: Oxford University Press.

Müller, J. W. (2016). Protecting popular self-government from the people? New normative perspectives on militant democracy. Annual Review of Political Science, 19, 249-265.

Pemstein, D., Marquardt, K. L., Tzelgov, E., Wang, Y., Medzihorsky, J., Krusell, J., Miri, F., \& Römer, J. von (2020). The V-Dem measurement model: Latent variable analysis for cross-national and crosstemporal expert-coded data. V-Dem Working Paper 21, 5th edition.

Persson, T., Roland, G., \& Tabellini, G. (1997). Separation of Powers and Political Accountability. Quarterly Journal of Economics, 112, 310-327.

Popper, K. R. (1944). The open society and its enemies. London: Routledge and Kegan Paul.

Prempeh, H. K. (2008). Presidents untamed. Journal of Democracy, 19(2), 109-123.

Röpke, W. (1962). Epochenwende. In: Wilhelm Röpke, Wirrnis und Wahrheit. Ausgewählte Aufsätze. Stuttgart: E. Rentsch Verlag, 105-124.

Rubio, D. F., \& Goretti, M. (1998). When the president governs alone. In J. M. Carey \& M. S. Shugart (Eds.), Executive decree authority (pp. 33-61). Cambridge: Cambridge University Press.

Rüstow, A. (1929/1959). Diktatur in den Grenzen der Demokratie, Vortrag vor der Deutschen Hochschule für Politik am 5.6.1929. Vierteljahreshefte für Zeitgeschichte, 7(1), 87-102.

Sajó, A. (2019). Militant constitutionalism. In A. Malkopoulou \& A. Kirshner (Eds.), Militant democracy and its critics: Populism, parties, extremism. Edinburgh: Edinburgh University Press.

Svolik, M. W. (2015). Which democracies will last? Coups, incumbent takeovers, and the dynamic of democratic consolidation. British Journal of Political Science, 45(4), 715-738.

van Aaken, A. (2009). Independent electoral management bodies and international election observer missions: Any impact on the observed level of democracy? A conceptual framework. Constitutional Political Economy, 20(3-4), 296-322.

van Aaken, A., Feld, L. P., \& Voigt, S. (2010). Do independent prosecutors deter political corruption? An empirical evaluation across seventy-eight countries. American Law and Economics Review, 12(1), 204-244. 
van Aaken, A., \& Voigt, S. (2011). Do individual disclosure rules for parliamentarians improve government effectiveness? Economics of Governance, 12(4), 301-324.

van Cranenburgh, O. (2009). Restraining executive power in Africa: horizontal accountability in Africa's hybrid regimes. South African Journal of International Affairs, 16(1), 49-68.

van Ham, C., \& Garnett, H. A. (2019). Building impartial electoral management? Institutional design, independence and electoral integrity. International Political Science Review, 40(3), 313-334.

Voigt, S. (2012). How to measure the rule of law. Kyklos, 65(2), 262-284.

Voigt, S. (2020). Constitutional economics: A primer. Cambridge: Cambridge University Press.

Voigt, S. (2021). Mind the gap: Analyzing the divergence between constitutional text and constitutional reality. Forthcoming: International Journal of Constitutional Law.

Voigt, S., \& Gutmann, J. (2013). Turning cheap talk into economic growth: On the relationship between property rights and judicial independence. Journal of Comparative Economics, 41(1), 66-73.

Voigt, S., Gutmann, J., \& Feld, L. P. (2015). Economic growth and judicial independence, a dozen years on: Cross-country evidence using an updated set of indicators. European Journal of Political Economy, 38, 197-211.

Wagrandl, U. (2018). Transnational militant democracy. Global Constitutionalism, 7(2), 143-172.

Publisher's Note Springer Nature remains neutral with regard to jurisdictional claims in published maps and institutional affiliations. 